\title{
A zsírdús étrend indukálta steatosis és a bél-máj tengely változásai
}

\author{
Blázovics Anna dr. ${ }^{1}$ - Sipos Péter dr. ${ }^{2}$ - Kocsis Ibolya dr. ${ }^{3}$ \\ Fébel Hedvig dr. ${ }^{4}$ - Kleiner Dénes dr. ${ }^{1}$ \\ Szentmihályi Klára dr. ${ }^{1,5}$. Fehér Erzsébet dr. ${ }^{2}$ \\ ${ }^{1}$ Semmelweis Egyetem, Gyógyszerésztudományi Kar, Farmakognóziai Intézet, Budapest \\ ${ }^{2}$ Semmelweis Egyetem, Orvostudományi Kar, Anatómiai, Szövet- és Fejlődéstani Intézet, Budapest \\ ${ }^{3}$ Semmelweis Egyetem, Orvostudományi Kar, Laboratóriumi Medicina Intézet, Budapest \\ ${ }^{4}$ NAIK Állattenyésztési, Takarmányozási és Húsipari Kutatóintézet, Herceghalom \\ ${ }^{5}$ Természettudományi Kutatóközpont, Anyag- és Környezetkémiai Intézet, Budapest
}

Bevezetés: A zsírmáj kialakulhat betegségek, mútétek, gyógyszerek, éhezés vagy túlzott mértékű alkoholfogyasztás következtében, de a helytelen táplálkozást, a zsírbő és rostszegény étkezést tartják az elsődleges oknak. A nem alkoholos zsírmájbetegség a lakosság 20-30\%-át érintheti. A táplálkozási eredetû zsírmájat korai stádiumban általában szövődménymentes májkárosodásnak írják le.

Célkitüzés: Kutatásaink célja a zsírdús táplálkozás bél-máj tengelyre gyakorolt hatásának a feltérképezése volt. Módszerek: Rutinlaboratóriumi, analitikai és szövettani módszerekkel patkányokban vizsgáltuk a bél és a máj redoxparamétereit, valamint a máj zsírsavösszetételét és elemtartalmát.

Eredmények: A máj elzsírosodása során a vérszérumban mérhető májenzim- és metabolitértékek eltérései mellett a redox-homeosztázis mutatóiban is szignifikáns változások igazolódtak. Változás volt kimutatható a májban, a vérben és a belekben. A máj elzsírosodásának folyamata együtt jár a transzmetiláló képesség csökkenésével. Megváltozott a zsírsavösszetétel és a fémion-homeosztázis is a májban. Szövettani vizsgálatoknál a májlobulusok centrális részén a hepatocyták megduzzadtak, bennük zsírcseppek láthatók, piknotikus sejtmagok alakultak ki, ami a zsíros elfajulásra jellemző. A vékony- és vastagbél enterocytái sérültek, helyenként lelökődtek a felszínről, és gyulladásos reakciók figyelhetók meg a nyálkahártyában.

Következtetés: Eredményeink alapján leszögezhető, hogy a zsírdús diéta okozta steatosis már korai stádiumban sem tekinthető egyszerüen reverzibilis változásnak, mert a változások kedvezőtlenül befolyásolják az egész szervezet redox-homeosztázisát, és egyben alapját képezhetik súlyos szív- és metabolikus betegségeknek, valamint siettethetik a gastrointestinalis tumorok kialakulását.

Orv Hetil. 2020; 161(35): 1456-1465.

Kulcsszavak: alimentáris eredetû zsírmáj, bél-máj tengely, redox-homeosztázis, fémion-anyagcsere, transzmetilezés, szövettan

\section{Fat rich diet-induced steatosis and changes in the gut-liver axis}

Introduction: Fatty liver can develop as a result of diseases, surgical procedures, medicaments, malnutrition or excessive alcohol consumption, however, fat and poor fiber feeding can be attributed as the primary cause. Non-alcoholic fatty liver can be found in $20-30 \%$ of the population. Generally, alimentary-induced fatty liver in early state is described as uncomplicated liver injury.

Aim: The aim of our research was to study the effect of fat rich nutrition on the gut-liver axis by routine laboratory, analytical and histological methods in rats.

Methods: We also examined the redox parameters of the liver and of the bowel. Fatty acid composition and element content of liver were measured.

Results: Significant changes were found in parameters of redox homeostasis as well as alterations in liver enzymes and metabolites. The changes could be detected in the liver, blood and bowel parts. The development of fatty liver is associated with the decrease of transmethylation capacity. Fatty acid composition and metal ion homeostasis were also 
altered in liver. Histological examinations showed that hepatocytes were swollen in the central part of the liver lobules, showed droplets and pycnotic nuclei, which were characterized by fatty degeneration. Small and large bowel enterocytes were damaged, sometimes pushed from the surface, and sometimes inflammatory reactions in the mucous membrane were observed.

Conclusion: Our results suggest that alimentary fatty liver in early state is not considered simply as a reversible alteration because it alters the entire body's redox homeostasis and establishes heart and serious metabolic diseases as well as hasten the development of gastrointestinal tumors.

Keywords: alimentary induced fatty liver, gut-liver axis, redox homeostasis, metal ion homeostasis, transmethylation, histology

Blázovics A, Sipos P, Kocsis I, Fébel H, Kleiner D, Szentmihályi K, Fehér E. [Fat rich diet-induced steatosis and changes in the gut-liver axis]. Orv Hetil. 2020; 161(35): 1456-1465.

(Beérkezett: 2020. március 10; elfogadva: 2020. április 4.)

\section{Rövidítések}

ALP = alkalikus foszfatáz; ALT/GPT = alanin-aminotranszferáz/glutamát-piruvát-transzamináz; $\mathrm{AOAC}=$ American Association of Official Analytical Chemists; ASE = aszkorbinsavekvivalens; AST $/$ GOT = aszpartát-aminotranszferáz/glutamát-oxálacetát-transzamináz; ATP = adenozin- 5 '-trifoszfát; $\mathrm{CHOL}=$ koleszterin $; \mathrm{COX} 2$ = ciklooxigenáz- 2 ; CREA = kreatinin; $\mathrm{DNS}=$ dezoxiribonukleinsav; $\mathrm{DPPH}=1,1$-difenil2-pikrilhidrazil; $\mathrm{EGF} \alpha=$ epithelial growth factor alpha; FGF = fibroblast growth factor; FID = (flame-ionisation detector $)$ lángionizációs detektor; GLUC = glükóz; $\mathrm{HCHO}=$ formaldehid; $\mathrm{HDL}=$ high-density lipoprotein; HDL-CHOL = HDL-koleszterin; ICP-OES = (inductively coupled plasma-optical emission spectrometry) induktív gerjesztésû plazma optikai emissziós spektrométer; IFCC = International Federation of Clinical Chemistry; IL1, IL6, IL8 = interleukinek; iNOS = indukálható nitrogén-monoxid-szintáz; $\mathrm{KCl}=$ kálium-klorid; mRNS = messenger RNS; NADH = redukált nikotinamid-adenin-dinukleotid; NADPH = redukált nikotinamid-adenin-dinukleotid-foszfát; NAFLD $=($ non-alcoholic fatty liver disease $)$ nem alkoholos eredetû zsírmáj; NFGF = new acidic fibroblast growth factor; OPLC $=$ (overpressured layer chromatography $)$ magas nyomású vékonyréteg-kromatográfia; $\mathrm{OsO}_{4}=$ ozmiumtetroxid; $\mathrm{PDGF}=$ platelet-derived growth factor; $\mathrm{PIP}_{2}=$ foszfoinozitol-difoszfát; $\mathrm{PLC}=$ foszfolipáz C; RLU $=$ (relative light unit) relatív fényegység; RNS = ribonukleinsav; $\mathrm{SOD}=$ szuperoxid-dizmutáz; TBIL = összbilirubin; TG = triglicerid; TGF $\beta=$ transforming growth factor beta; $\mathrm{TNF} \alpha=$ tumor necrosis factor alpha; TNF $\beta$ = tumor necrosis factor beta; UA = húgysav; $\mathrm{WHO}=$ World Health Organization

A nem alkoholos eredetú zsírmáj (non-alcoholic fatty liver disease - NAFLD) leggyakoribb okai a helytelen táplálkozási szokások, a zsírbő és rostszegény étrend következtében kialakuló hyperlipidaemia és obesitas. Azonban a zsírmáj kialakulhat például intestinalis bypassmútétek, hasi sebészeti beavatkozások, kiterjedt vékonybél-reszekciók, gyulladásos bélbetegségek, Crohn-betegség, gluténszenzitív enteropathia kapcsán is, de éhezés és fehérjehiány is vezethet zsírmájhoz. Az ösztrogént tartalmazó gyógyszerek, orális fogamzásgátlók, hormonterá- piás gyógyszerek stb. hasonlóképpen hozzájárulhatnak a máj károsodásához, és egyben növelhetik az epekőbetegség kialakulásának rizikóját [1].

$\mathrm{Az}$ étrendi eredetű zsírmájat reverzibilis változásnak tekintik, azonban a nem alkoholos zsírmájból (a lakosság kb. 2-3\%-ánál) kialakulhat steatohepatitis, cirrhosis és ritkán májrák is. A zsírmáj a legújabb kutatások szerint a metabolikus szindróma hepaticus megjelenési formája, és szoros kapcsolatban van a 2 -es típusú cukorbetegséggel, illetve egyre több adat igazolja szoros kapcsolatát más extrahepaticus betegségekkel [2]. Hegedüs és mtsai kísérletes zsírmájban a COX2-mRNS-, a TNF $\alpha-m R N S-$ és az iNOS-mRNS-szintek növekedésével alacsony szintû gyulladást igazoltak a májban [3].

$\mathrm{Az}$ utóbbi években egyre nagyobb figyelem irányul a bél-máj tengelyre, és számos közlemény jelenik meg a gyulladásos bélbetegségekkel és a májcirrhosissal kapcsolatban, ami hangsúlyozza e két szerv kölcsönös egymásra hatását [4-8].

Ma már elfogadott tény, hogy a bélmikrobióta összetétele és metabolikus kapacitása hozzájárul a gazdaszervezet anyagcseréjének szabályozásához. A tápanyagok viszont jelentősen befolyásolják a bél mikroflóráját [9].

Kutatócsoportunk már az 1990-es évek elején felfigyelt arra, hogy a kísérletes alkoholos májkárosodás és a lipidterhelés a jejunum struktúráját is kedvezôtlenül érinti, és a feltételezett szabad gyökös károsodásokat a Sempervivum tectorum kivonatának (kövirózsa préslevének liofilizátuma) polifenolos vegyületeivel mérsékelni lehet [10]. Gyulladásos bélbetegségek retrospektív tanulmányozásakor azt találtuk, hogy a májenzimértékek kismértékủ emelkedése mellett mind az összantioxidánsstátusz, mind a szérumepesav szintje szignifikánsan lecsökken, és prediktív faktornak tekinthetô colitis ulcerosában [11]. Kísérletes zsírmájban patkányok kanülált epéjét egészséges állatok passzázsból kirekesztett, de keringését megtartott colon coecumhoz közeli szakaszára fecskendezve rövid idő alatt már jelentős szövetkárosodást figyeltünk meg a kontrollepével kezelt egyedekhez 
képest. A károsodást a szabad gyökös reakciók felerősödésével is magyaráztuk [12]. Amennyiben az állatok Raphanus sativus niger préslé (fekete retek préslé) kezelésben is részesültek, a károsodás mértéke kisebb volt, ami a növényben található polifenolos vegyületeknek és az izotiocianát-tartalomnak is köszönhetően primer és szekunder módon csökkentette a szabad gyökös ártalmakat [13]. Humán tanulmányban igazoltuk, hogy a cholecystectomián átesett betegek epéjében diénkonjugátumok és malondialdehid mutatható ki, ami a májból származó lipidperoxidáció következtében károsodott lipidek, mint prekurzor molekulák láncreakciójából eredeztethető [14]. Állatkísérletekben igazoltuk a lipidperoxidációs folyamatok felerősödését zsírmájban. Zsírmájban szignifikánsan változik az epe összetétele, módosul az epetermelés és az epeelfolyás is [15]. Ezekből a kísérletekből arra a következtetésre jutottunk, hogy a fokozott szabad gyökös tevékenység is hozzájárulhat az epekőképződéshez [16, 17].

Az epében a szabad gyökös reakciókat fokozhatja a májból az epével ürülő átmeneti fémek jelenléte, mely felerôsíti az epekövek képződését [18].

Jelen munkánk célja annak megerősítése, hogy már az alimentáris eredetű zsírmáj sem tekinthető csupán reverzibilis májkárosodásnak, mert a több szervet is érintó elváltozások felgyorsítják az úgynevezett népbetegségnek számító keringési és gastrointestinalis betegségek kialakulását.

\section{Módszerek}

A kísérleteinkben felhasznált reagenseket és diagnosztikai készleteket magyarországi kirendeltségeken keresztül szereztük be.

\section{Állatkisérlet}

Kísérleteinkben 180-200 g-os hím Wistar patkányokat (Charles River Magyarország Kft., Budapest) használtunk. Az állatokban alimentáris zsírmájat idéztünk elő a standard táphoz adott 2\% koleszterin-, 0,5\% kólsav- és 20\%-os napraforgóolaj-tartalmú táp 14 napos „short term” etetésével [10]. A patkányok terminálásakor narkotikumként $35 \mathrm{mg}$ Nembutalt alkalmaztunk testtömeg kg-onként. Az állatokat a vena abdominalison keresztül kivéreztettük. A vért Vacutainer (Fisher Scientific, Waltham, MA, USA) vérvételi csövekben fogtuk fel, majd ezt követően eltávolítottuk a májakat és a vékony- és vastagbélszakaszokat. A májakat izotóniás KCl-oldattal mostuk és aprítottuk, majd a vérmentes májszövetet Potter-Elvehjem-készülékben homogenizáltuk.

A patkányok bélszakaszainak azonosítása után az adott bélszakaszokat kivágtuk, majd az elkülönített szakaszokból a béltartalmat óvatosan kinyomtuk, és izotóniás $\mathrm{KCl}$ oldattal bélsármentesre mostuk. A bélmucosát a bél külső felszíne felől erőteljes nyomással eltávolítottuk. A preparálás múveleteit jeges hûtés mellett végeztük.
A kísérletek során betartottuk a WHO és a Helsinki Deklarátum követelményeit (Magyar Közlöny, 1998). Engedélyszám: Pest Megyei Állategészségügyi és Élelmiszer-ellenőrző Állomás, 770/004/04.

\section{Enzimaktivitás- és metabolitkoncentráció- meghatározások vérből}

Citrátos plazmából vagy szérumból történtek a mérések. Meghatároztuk az alkalikus foszfatáz (ALP), alanin-aminotranszferáz (ALT/GPT), aszpartát-aminotranszferáz (AST/GOT), kreatinin (CREA), vércukor (GLUC), koleszterin (CHOL), HDL-koleszterin, triglicerid (TG), húgysav (UA), összbilirubin (TBIL) paramétereket diagnosztikus készletek (Dialab, Randox, Roche, Reanal) segítségével a gyártó útmutatásai alapján Hitachi 717 automata kémiai analizátorral.

\section{A fehérjetartalom meghatározása}

A máj- és bélmucosa-homogenizátumok fehérjetartalmát Lowry és mtsai [19] módszerével határoztuk meg, és bovin-szérumalbuminra nézve $10 \mathrm{mg} / \mathrm{ml}$, illetve $5 \mathrm{mg} /$ ml koncentrációjúra állítottuk be, majd ezekből a mintákból a mérések során azonos térfogatokat (50-100 l) vittünk be a mérőrendszerekbe.

\section{A redukálóképesség meghatározása}

A redukálóképességet Oyaizu szerint [20] határoztuk meg. A $10 \mathrm{mg} / \mathrm{ml}$ fehérjetartalmú szöveti homogenizátumok esetében $200 \mu \mathrm{l}$ mintát használtunk fel a méréshez. A minta redukálóképességét aszkorbinsav-ekvivalensben (ASE) adtuk meg.

\section{A H-donor-aktivitás meghatározása}

A H-donor-aktivitást Blois módszerének kis módosítása [21] alapján 1,1-difenil-2-pikrilhidrazil stabil gyök jelenlétében mértük 517 nm-en spektrofotometriásan. Az eredményt gátlás\%-ban adtuk meg.

\section{A diénkonjugátum-koncentráció meghatározása májból}

A májhomogenizátumok lipidtartalmát izooktánnal extraháltuk, és az AOAC (1984) útmutatása szerint spektrofotometriásan $232 \mathrm{~nm}$-en határoztuk meg [22].

\section{Az összscavenger-kapacitás meghatározása}

Az összscavenger-kapacitás meghatározására kemilumineszcenciás módszert alkalmaztunk Blázovics és mtsai szerint. Az eredményeket relative light unit (RLU) egységben adtuk meg. A bemérésnél $150 \mu$ plazmát, $50 \mu \mathrm{l}$ 
$10 \mathrm{mg} / \mathrm{ml}$-es májhomogenizátumot és $60 \mu \mathrm{l} 10 \mathrm{mg} /$ ml-es bélhomogenizátumokat mértünk a standard mérőrendszerbe [23].

\section{A szabad szulfhidrilcsoportok meghatározása}

A szabad szulfhidrilcsoport koncentrációit a Sedlak és Lindsay által módosított Ellmann-módszerrel határoztuk meg 5,5-ditiobisz-nitrobenzoesav reagenssel $\mathrm{pH}$ 7,4-es Na-foszfát-pufferben, $512 \mathrm{~nm}$-en spektrofotometriásan. Standardként redukált glutationt használtunk [24].

\section{A transzmetilációs képesség vizsgálata magas nyomású vékonyréteg-kromatográfiás (OPLC) meghatározással}

A kötött formaldehidet formaldemeton addukt formájában határoztuk meg túlnyomásos rétegkromatográfiával. A kromatográfiás elválasztást szilikagél $80 \mathrm{~F}_{254}$ kromatográfiás lemezeken végeztük (Merck Co., Darmstadt, Németország), kloroform-metilén-klorid keverék $(35: 65, \mathrm{~V} / \mathrm{V})$ felhasználásával. A patkánymáj-homogenizátumokat dimedonoldattal kezeltük $(0,05 \%$ dimedon-metanolos oldat/24 óra), majd a szuszpenziót 1500 g-vel 10 percig $4{ }^{\circ} \mathrm{C}$-on centrifugáltuk. A tiszta felülúszókat használtuk kromatográfiás elválasztásra [21].

\section{Zsirsav-meghatározás gázkromatográfiás módszerrel}

A lipideket Folch és mtsai [25] szerint vontuk ki a májmintákból. A lipidekben lévő zsírsavak metil-észtereit bór-trifluorid-módszerrel [26] képeztük. A zsírsavak mennyiségi meghatározásához nonadekánsavat használtunk belső standardként. A zsírsavak metil-észtereit FID-detektorral felszerelt Shimadzu 2010 (Shimadzu Corporation, Tokio, Japán) típusú gázkromatográffal analizáltuk. Az elválasztáshoz SP-2380 kapilláriskolonnát $(30 \mathrm{~m} \times 0,25 \mathrm{~mm}, 0,25 \mu \mathrm{m}$ filmvastagság; Supelco, Inc. Bellefonte, PA, USA) használtunk. A gázkromatografálás körülményei a következők voltak: injektor $270{ }^{\circ} \mathrm{C}$, detektor $300{ }^{\circ} \mathrm{C}$, kolonna $80^{\circ} \mathrm{C} 1$ percig, majd melegítés $2,5{ }^{\circ} \mathrm{C} /$ perc sebességgel $205^{\circ} \mathrm{C}$-ig, $205^{\circ} \mathrm{C}$ on 5 percig, majd $10^{\circ} \mathrm{C} /$ perc sebességgel $250^{\circ} \mathrm{C}$-ig, és 5 percig ezen a hőfokon maradt. Vivőgázként héliumot használtunk, amelynek áramlási sebessége: $28 \mathrm{~cm} / \mathrm{s}$. A mérésnél a 'split' arány 1 : 50 volt. A mintában lévő zsírsav-metil-észter-csúcsokat ismert összetételű referenciaoldatban (Mixture Me 100, Larodan Fine Chemicals $\mathrm{AB}$, Solna, Svédország) lévő zsírsavak retenciós ideje alapján azonosítottuk.

\section{Elemanalizis induktín gerjesztésu" plazma optikai emissziós spektrométerrel (ICP-OES)}

A májmintákból 500-500 mg-ot $5 \mathrm{ml}$ 65\%-os salétromsav és $2 \mathrm{ml} \mathrm{H}_{2} \mathrm{O}_{2}$ elegyével mikrohullámú feltáróban roncsoltunk. Az elemtartalmak mérésére SPECTRO GENESIS ICP-OES (SPECTRO, Kleve, Németország) és iCAP Q ICP-MS (ThermoFisher Scientific, Waltham, MA, USA) készüléket használtunk multielemes standardok (MU33 multielement standard, $100 \mathrm{mg} / \mathrm{l}$, CPAChem Product, Stara Zagora, Bulgária és EPA30 multielement standard, 5-100 mg/l, Bernd Kraft $\mathrm{GmbH}$, Duisburg, Németország) segítségével [27].

\section{Szövettani vizsgálatok}

A kivett máj- és bélmetszeteket fény- és elektronmikroszkópos vizsgálatra készítettük elő. A fénymikroszkópos vizsgálatokhoz a kis anyagrészeket $4 \%$-os formaldehiddel fixáltuk, és hematoxilin-eozin festést használtunk. Az elekronmikroszkópos vizsgálathoz a kis anyagokat 4\% paraformaldehidet és $1 \%$ glutáraldehidet tartalmazó oldatban fixáltuk, majd $\mathrm{OsO}_{4}$-dal utófixáltuk. Az ultravékony metszeteket uranil-acetáttal és ólom-citráttal kontrasztoztuk, majd JEOL 100 elektronmikroszkóppal (JEOL Ltd., Tokió, Japán) vizsgáltuk.

\section{Statisztikai analizis}

Microsoft Excel, statGraph és Statistica 13 programokat, valamint a GaphPad 1.14-es verziójú szoftvert használtuk a mérések kiértékeléséhez. A kiértékelés varianciaanalízissel történt. Alkalmaztuk a Student-féle t-próbát. A kvantitatív vizsgálati eredményeket három párhuzamos mérés átlaga és szórása alapján értékeltük. A szignifikanciát 95\%-os valószínúségi szinten adtuk meg.

\section{Eredmények}

Az 1. és 2. táblázatban a kontroll- és a zsírdús táppal kezelt állatok szérumparamétereit tüntettük fel. Az enzimés lipidparaméterek változásai egyértelmúen megerősítik a máj károsodását. Szignifikáns eltérést kaptunk az ALP, CHOL, HDL-CHOL, UA és CREA esetében, míg az ALT és GLUC mérési eredmények tendenciájukban jelezték a májkárosodást a „short term” kezelés hatására.

A 3. táblázatban a plazma, a 4. táblázatban a máj redoxparamétereit foglaltuk össze. A redukálóképesség és a szabadszulfhidril-csoport (szabad-SH-csoport) koncentrációinak jelentős csökkenése és a lipidperoxidáció következtében a diénkonjugátumok felszaporodása a máj antioxidáns kapacitásának romlását jelzik. A redoxhomeosztázis károsodása szoros kapcsolatban van a szöveti transzmetilációs képesség csökkenésével, így látható, hogy a kötött formaldehid ( $\mathrm{HCHO})$ értékei - amelyek a metilcsoportok mennyiségét jelzik - is szignifikáns mér- 
1. táblázat | Szérumparaméterek (átlag \pm szórás)

\begin{tabular}{|c|c|c|c|c|c|c|}
\hline Csoportok & $\begin{array}{l}\text { ALP } \\
(\mathrm{U} / \mathrm{l})\end{array}$ & $\begin{array}{l}\text { ALT/GPT } \\
(\mathrm{U} / \mathrm{l})\end{array}$ & $\begin{array}{l}\text { AST/GOT } \\
(\mathrm{U} / \mathrm{l})\end{array}$ & $\begin{array}{l}\text { CHOL } \\
(\mathrm{mmol} / \mathrm{l})\end{array}$ & $\begin{array}{l}\text { HDL-CHOL } \\
(\mathrm{mmol} / \mathrm{l})\end{array}$ & $\begin{array}{l}\mathrm{TG} \\
(\mathrm{mmol} / \mathrm{l})\end{array}$ \\
\hline Kontrollmáj $(\mathrm{n}=9)$ & $811,5 \pm 37,4$ & $63,45 \pm 13,21$ & $196,5 \pm 6,36$ & $2,01 \pm 0,21$ & $1,153 \pm 0,068$ & $1,664 \pm 0,585$ \\
\hline Zsírmáj (n = 9) & $2048 \pm 264^{*}$ & $94,6 \pm 23,19$ & $179,5 \pm 24,7$ & $9,90 \pm 2,49 *$ & $0,866 \pm 0,012$ * & $0,835 \pm 0,205$ \\
\hline
\end{tabular}

Szignifikancia p<0,05 szignifikancia kontrollmáj vs. zsírmáj*

ALP = alkalikus-foszfatáz; ALT/GPT = alanin-aminotranszferáz; AST /GOT = aszpartát-aminotranszferáz; CHOL = koleszterin, HDL-CHOL = HDL-koleszterin; $\mathrm{TG}=$ triglicerid

2. táblázat | Szérumparaméterek (átlag \pm szórás)

\begin{tabular}{lllll}
\hline Csoportok & $\begin{array}{l}\text { TBIL } \\
(\mu \mathrm{mol} / \mathrm{l})\end{array}$ & $\begin{array}{l}\text { UA } \\
(\mu \mathrm{mol} / \mathrm{l})\end{array}$ & $\begin{array}{l}\text { CREA } \\
(\mu \mathrm{mol} / \mathrm{l})\end{array}$ & $\begin{array}{l}\text { GLUC } \\
(\mathrm{mmol} / \mathrm{l})\end{array}$ \\
\hline $\begin{array}{l}\text { Kontroll- } \\
\text { máj } \\
(\mathrm{n}=9)\end{array}$ & $2,15 \pm 6,33$ & $102 \pm 11$ & $37,8 \pm 0,21$ & $10,66 \pm 2,96$ \\
\hline $\begin{array}{l}\text { Zsírmáj } \\
(\mathrm{n}=9)\end{array}$ & $2,78 \pm 0,38$ & $138 \pm 19,09 *$ & $49,25 \pm 1,62^{*}$ & $8,65 \pm 1,52$ \\
\hline
\end{tabular}

Szignifikancia p<0,05 szignifikancia kontrollmáj vs. zsírmáj*

CREA = kreatinin; GLUC = glükóz; TBIL = összbilirubin; UA = húgysav

3. táblázat |A plazma redoxparaméterei (átlag \pm szórás)

\begin{tabular}{llll}
\hline Csoportok & $\begin{array}{l}\text { H-donor-aktivitás } \\
(\text { gátlás\% })\end{array}$ & $\begin{array}{l}\text { Redukálóképesség } \\
(\mu \mathrm{mol} \mathrm{AS} / \mathrm{ml})\end{array}$ & $\begin{array}{l}\text { Szabad-SH- } \\
\text { csoport }(\mathrm{mmol} / \mathrm{l})\end{array}$ \\
\hline $\begin{array}{l}\text { Kontrollmáj } \\
(\mathrm{n}=9)\end{array}$ & $38,92 \pm 2,28$ & $0,666 \pm 0,373$ & $0,221 \pm 0,046$ \\
\hline $\begin{array}{l}\text { Zsírmáj } \\
(\mathrm{n}=9)\end{array}$ & $33,77 \pm 1,04^{*}$ & $0,477 \pm 0,035^{*}$ & $0,103 \pm 0,033^{*}$ \\
\hline
\end{tabular}

Szignifikancia p<0,05 szignifikancia kontrollmáj vs. zsírmáj*

tékben csökkentek. A hidrogéndonáló képesség a plazmában kifejezettebb volt, mint a májban, ami azzal magyarázható, hogy a májban a zsíranyagcsere változásával együtt járó redukáló ekvivalensek (redukált nikotinamidadenin-dinukleotid-[foszfát]), a NADH- és NADPHkoncentrációk növekedése miatti redukáló többletet is méri a rendszer.

Az 5. és 6. táblázatban a vékony- és a vastagbél redoxparaméterei közül szignifikáns változás az enzimatikus antioxidáns védekezést is tükröző szabad szulfhidrilcsoport koncentrációjában mutatkozott, míg a másik két
5. táblázat A vékonybél redoxparaméterei (átlag „ szórás)

\begin{tabular}{llll}
\hline Csoportok & $\begin{array}{l}\text { H-donor-aktivitás } \\
\text { (gátlás\%) }\end{array}$ & $\begin{array}{l}\text { Redukálóképesség } \\
(\mu \mathrm{mol} \mathrm{AS} / \mathrm{mg} \\
\text { protein })\end{array}$ & $\begin{array}{l}\text { Szabad-SH- } \\
\text { csoport } \\
(\mathrm{mmol} / \mathrm{l})\end{array}$ \\
\hline $\begin{array}{l}\text { Kontrollmáj } \\
(\mathrm{n}=9)\end{array}$ & $95,38 \pm 0,64$ & $1,113 \pm 0,159$ & $0,968 \pm 0,089$ \\
\hline $\begin{array}{l}\text { Zsírmáj } \\
(\mathrm{n}=9)\end{array}$ & $94,98 \pm 1,82$ & $1,038 \pm 0,175$ & $1,078 \pm 0,065^{*}$ \\
\hline
\end{tabular}

Szignifikancia p<0,05 szignifikancia kontrollmáj vs. zsírmáj*

6. táblázat |A vastagbél redoxparaméterei (átlag \pm szórás)

\begin{tabular}{llll}
\hline Csoportok & $\begin{array}{l}\text { H-donor-aktivitás } \\
(\text { gátlás\% })\end{array}$ & $\begin{array}{l}\text { Redukálóképesség } \\
(\mu \mathrm{mol} \mathrm{AS} / \mathrm{mg} \\
\text { protein })\end{array}$ & $\begin{array}{l}\text { Szabad-SH- } \\
\text { csoport } \\
(\mathrm{mmol} / \mathrm{l})\end{array}$ \\
\hline $\begin{array}{l}\text { Kontrollmáj } \\
(\mathrm{n}=9)\end{array}$ & $80,64 \pm 14,79$ & $0,673 \pm 0,197$ & $0,738 \pm 0,150$ \\
\hline $\begin{array}{l}\text { Zsírmáj } \\
(\mathrm{n}=9)\end{array}$ & $79,38 \pm 16,18$ & $0,637 \pm 0,196$ & $0,530 \pm 0,128^{*}$ \\
\hline
\end{tabular}

Szignifikancia p<0,05 szignifikancia kontrollmáj vs. zsírmáj*

7. táblázat | Indukálható szabadgyök-szint (relative light unit; RLU) (átlag \pm szórás)

\begin{tabular}{lcccc}
\hline Csoportok & Plazma & Máj & Vékonybél & Vastagbél \\
\hline Kontrollmáj & 1515297 & 11315178 & 25927 & 16569092 \\
$(\mathrm{n}=9)$ & \pm & \pm & \pm & \pm \\
& 232648 & 870913 & 9151 & 3720149 \\
\hline Zsírmáj & $5530986^{*}$ & $15862892^{*}$ & $52513^{*}$ & $25248150^{*}$ \\
$(\mathrm{n}=9)$ & \pm & \pm & \pm & \pm \\
& 1624096 & 1156460 & 6984 & 3805403 \\
\hline
\end{tabular}

Szignifikancia p<0,05 szignifikancia kontrollmáj vs. zsírmáj*

4. táblázat |A máj redoxparaméterei (átlag \pm szórás)

\begin{tabular}{lllll}
\hline Csoportok & $\begin{array}{l}\text { H-donor-aktivitás } \\
(\text { gátlás\% })\end{array}$ & $\begin{array}{l}\text { Redukálóképesség } \\
(\mu \mathrm{mol} \text { AS } / \mathrm{mg} \text { protein })\end{array}$ & $\begin{array}{l}\text { Szabad-SH-csoport } \\
(\mathrm{mmol} / \mathrm{l})\end{array}$ & $\begin{array}{l}\text { Diénkonjugátum } \\
\left(\mathrm{Abs} \mathrm{s}_{233} / \mathrm{ml}\right)\end{array}$ \\
\hline Kontrollmáj $(\mathrm{n}=9)$ & $46,89 \pm 3,27$ & $0,132 \pm 0,015$ & $0,680 \pm 0,044$ & $0,278 \pm 0,071$ \\
\hline Zsírmáj $(\mathrm{n}=9)$ & $44,00 \pm 3,29$ & $0,107 \pm 0,022^{*}$ & $0,485 \pm 0,106^{*}$ & $0,803 \pm 0,101^{*}$ \\
\hline
\end{tabular}

Szignifikancia p<0,05 szignifikancia kontrollmáj vs. zsírmáj*

$\mathrm{HCHO}=$ formaldehid 
8. táblázat

A patkánymáj zsírsavtartalma

\begin{tabular}{|c|c|c|}
\hline $\begin{array}{l}\text { Zsírsavak } \\
\text { (mg/g máj) }\end{array}$ & $\begin{array}{l}\text { Kontrollmáj }(\mathrm{n}=9) \\
\text { (átlag } \pm \text { szórás) }\end{array}$ & $\begin{array}{l}\text { Zsírmáj }(\mathrm{n}=9) \\
\text { (átlag } \pm \text { szórás) }\end{array}$ \\
\hline C14:0 (mirisztinsav) & $0,08 \pm 0,02$ & $0,25 \pm 0,06^{*}$ \\
\hline C15:0 (pentadekánsav) & $0,05 \pm 0,01$ & $0,13 \pm 0,02$ * \\
\hline C16:0 (palmitinsav) & $3,53 \pm 0,35$ & $8,41 \pm 1,38$ * \\
\hline C16:1 (palmitoleinsav) & $0,24 \pm 0,0,7$ & $0,70 \pm 0,22$ * \\
\hline C17:0 (heptadekánsav) & $0,09 \pm 0,02$ & $0,14 \pm 0,02 *$ \\
\hline C18:0 (sztearinsav) & $3,16 \pm 0,42$ & $3,56 \pm 0,29$ * \\
\hline C18:1 (olajsav) & $1,38 \pm 0,16$ & $21,32 \pm 2,59^{*}$ \\
\hline C18:2 (linolsav) & $3,24 \pm 0,43$ & $44,92 \pm 4,68^{*}$ \\
\hline C18:3 (linolénsav) & $0,05 \pm 0,01$ & $0,36 \pm 0,11$ * \\
\hline C20:0 (arachidsav) & $0,01 \pm 0,00$ & $0,11 \pm 0,02$ * \\
\hline C20:1 (eikozénsav) & $0,04 \pm 0,01$ & $0,48 \pm 0,08 *$ \\
\hline C20:2 (eikozadiénsav) & $0,16 \pm 0,03$ & $1,52 \pm 0,36^{*}$ \\
\hline C20:3n3 (eikozatriénsav) & $0,81 \pm 0,15$ & $2,48 \pm 0,33^{*}$ \\
\hline C20:4 (arachidonsav) & $5,58 \pm 0,59$ & $8,09 \pm 0,96^{*}$ \\
\hline C20:5 (eikozapentaénsav) & $0,04 \pm 0,01$ & $0,05 \pm 0,02$ \\
\hline C22:6 (dokozahexaénsav) & $1,43 \pm 0,17$ & $0,98 \pm 0,14^{*}$ \\
\hline C24:0 (lignocerinsav) & $0,02 \pm 0,01$ & $1,22 \pm 0,38$ * \\
\hline C24:1 (nervonsav) & $0,16 \pm 0,01$ & $1,09 \pm 0,27$ * \\
\hline Összes zsírsav mg/g máj & $19,38 \pm 1,84$ & $95,80 \pm 8,87^{*}$ \\
\hline
\end{tabular}

Szignifikancia p<0,05 szignifikancia kontrollmáj vs. zsírmáj*

paraméter csak mérsékelt eltérést mutatott, ami a vékonybél jobb antioxidáns-ellátottságának tulajdonítható. Azonban a vékony- és vastagbél mindhárom redoxparaméterének statisztikai vizsgálatakor szignifikáns eltérést kaptunk az eltérő bélszakaszok között.

A 7. táblázatban a szöveti antioxidáns-status luminometriás vizsgálatának eredményei láthatók. A szervek eltérő antioxidáns-tartalmú vegyületeinek és enzimaktivitásainak következtében csak a kezelt és kontrollállatok közötti különbségeket (szöveti enzimatikus és nem enzi-
9. táblázat |A patkánymáj elemösszetétele

\begin{tabular}{|c|c|c|}
\hline $\begin{array}{l}\text { Elemek } \\
(\mu \mathrm{g} / \mathrm{g})\end{array}$ & $\begin{array}{c}\text { Kontrollmáj }(\mathrm{n}=9) \\
\text { (átlag } \pm \text { szórás })\end{array}$ & $\begin{array}{l}\text { Zsírmáj ( } \mathrm{n}=9 \text { ) } \\
\text { (átlag } \pm \text { szórás) }\end{array}$ \\
\hline $\mathrm{Al}$ & $0,454 \pm 0,102$ & $0,552 \pm 0,225$ \\
\hline As & $<0,1$ & $<0,1$ \\
\hline $\mathrm{Ba}$ & $0,324 \pm 0,125$ & $0,459 \pm 0,035$ \\
\hline $\mathrm{Ca}$ & $4,05 \pm 0,55$ & $5,47 \pm 2,14$ \\
\hline $\mathrm{Cd}$ & $0,0229 \pm 0,0083$ & $0,0393 \pm 0,0161$ \\
\hline $\mathrm{Co}$ & $0,0661 \pm 0,0101$ & $0,0818 \pm 0,0043$ * \\
\hline $\mathrm{Cr}$ & $0,0564 \pm 0,0256$ & $0,0320 \pm 0,0074$ \\
\hline $\mathrm{Cu}$ & $0,304 \pm 0,046$ & $0,264 \pm 0,009$ \\
\hline $\mathrm{Fe}$ & $5,65 \pm 0,76$ & $4,22 \pm 0,93$ \\
\hline $\mathrm{K}$ & $170,1 \pm 25,1$ & $154,7 \pm 8,5^{*}$ \\
\hline $\mathrm{Li}$ & $0,106 \pm 0,036$ & $0,084 \pm 0,040$ \\
\hline $\mathrm{Mg}$ & $9,39 \pm 0,60$ & $6,99 \pm 0,54^{*}$ \\
\hline $\mathrm{Mn}$ & $0,122 \pm 0,006$ & $0,086 \pm 0,062$ \\
\hline Mo & $0,0707 \pm 0,0324$ & $0,0261 \pm 0,0048$ * \\
\hline $\mathrm{Ni}$ & $0,202 \pm 0,166$ & $0,070 \pm 0,025$ \\
\hline $\mathrm{P}$ & $160,4 \pm 7,5$ & $135,4 \pm 14,8 *$ \\
\hline $\mathrm{Pb}$ & $0,360 \pm 0,035$ & $0,460 \pm 0,015^{*}$ \\
\hline S & $95,36 \pm 11,05$ & $70,02 \pm 7,43^{*}$ \\
\hline Se & $0,0218 \pm 0,0082$ & $0,0213 \pm 0,0088$ \\
\hline $\mathrm{Sr}$ & $0,0262 \pm 0,0068$ & $0,0281 \pm 0,0029$ \\
\hline $\mathrm{Zn}$ & $1,36 \pm 0,06$ & $1,17 \pm 0,14^{*}$ \\
\hline
\end{tabular}

Szignifikancia p<0,05 szignifikancia kontrollmáj vs. zsírmáj*

matikus védekezés elemei, fémion-összetétel, lipidprofil) tudjuk érdemben összehasonlítani, a szervek közötti eltéréseket ez a „globális” vizsgálati módszer nem tudja elkülöníteni.

Az összes vizsgált szerv összscavenger-kapacitása zsírmáj esetében szignifikánsan rosszabb értékeket mutat, mint a kontrollcsoport állatainak szervei. A 7. táblázatban a fényintenzitás mértékét jelző RLU (relatív fényegység) növekedése az antioxidáns védekezőképesség csökkenését jelenti.
A)

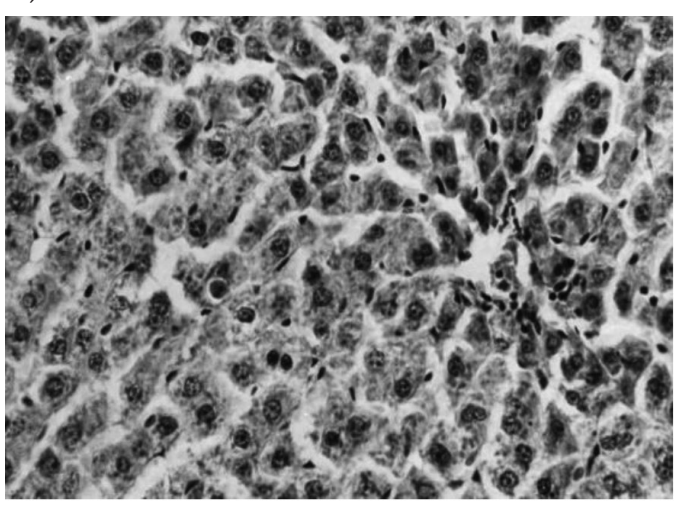

B)

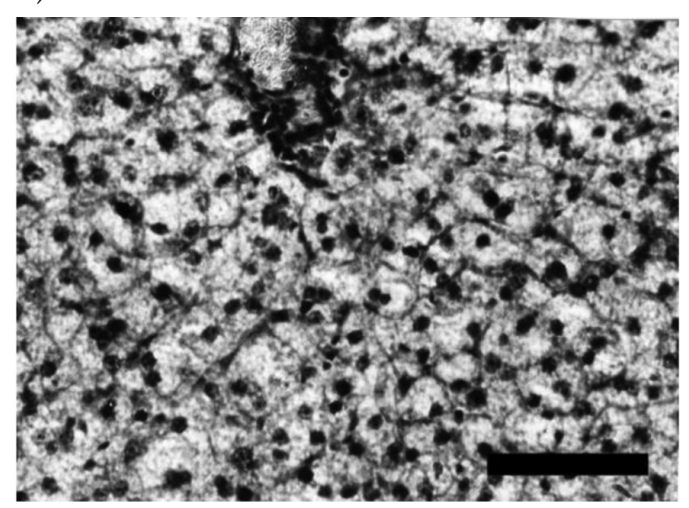

1. ábra A májsejt fénymikroszkópos képe egészséges állatokban és zsírmájban szenvedőkben A) Egészséges májsejt; B) Zsírcseppeket tartalmazó májsejt

Lépték: 50 mikrométer 
A)

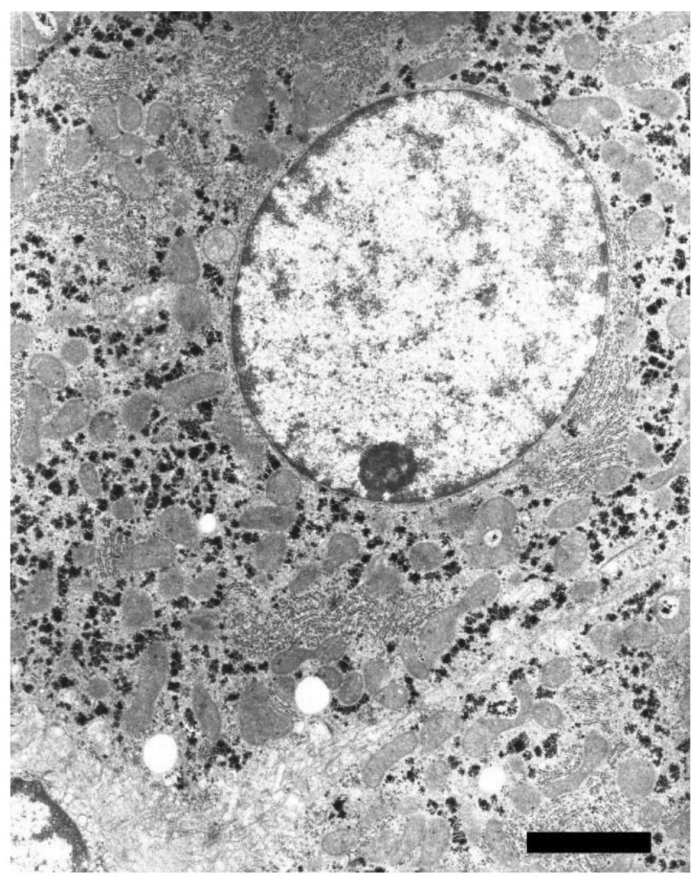

B)

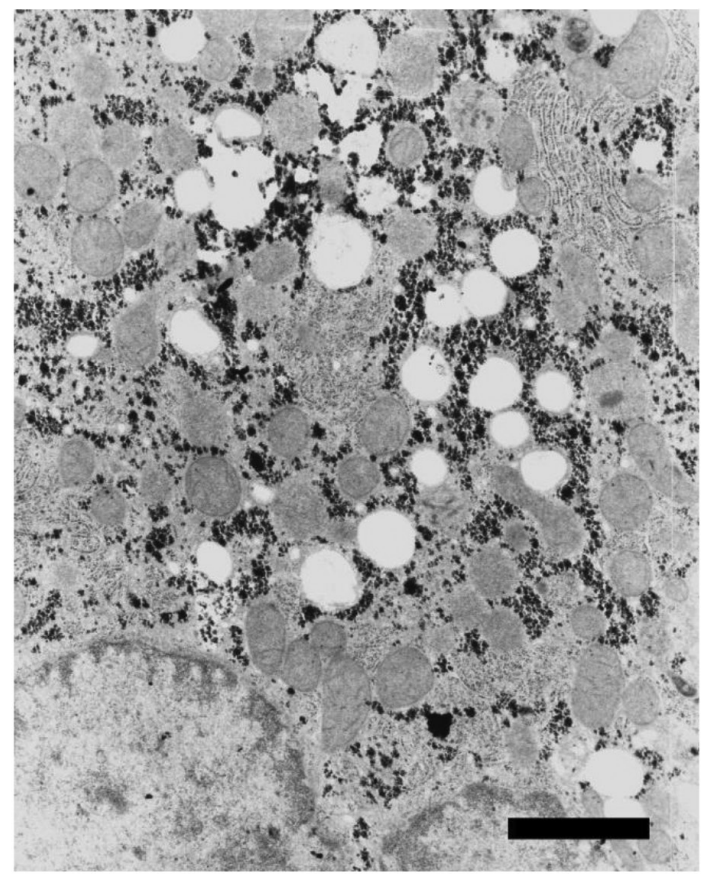

2. ábra $\mid$ A májsejt elektronmikroszkópos képe egészséges állatokban és zsírmájban szenvedókben

A) Egészséges májsejt; B) Zsírcseppeket tartalmazó májsejt

Lépték: 1 mikrométer

A)

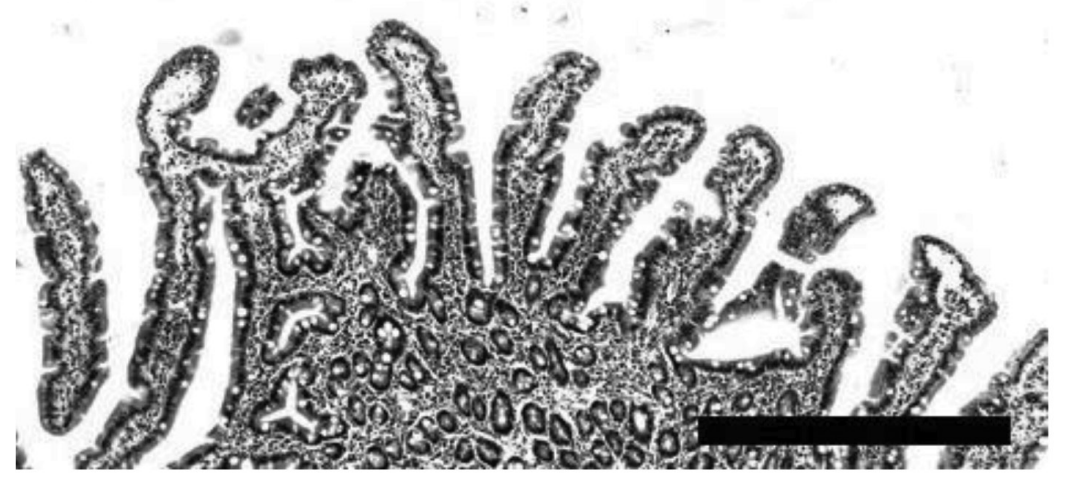

B)

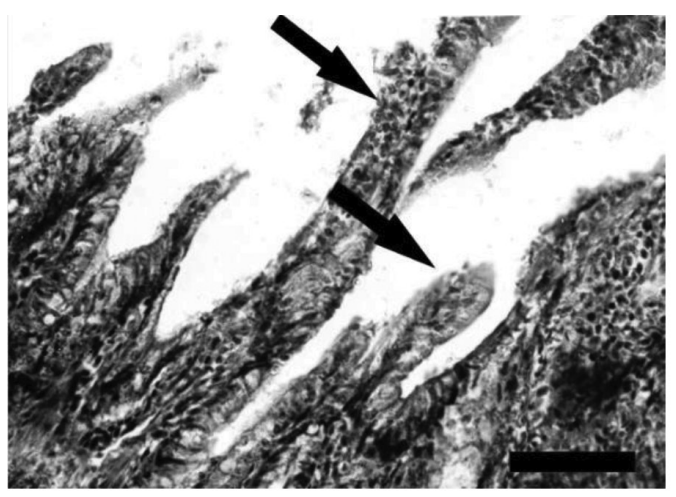

C)

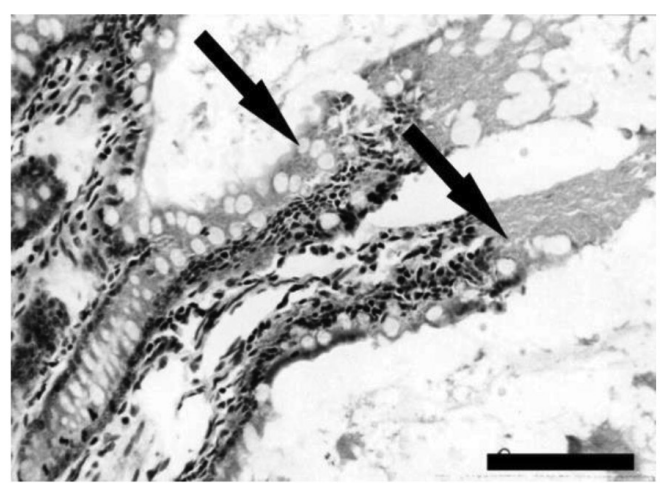

3. ábra

A vékonybél fénymikroszkópos képe zsírmájban szenvedókben

A) Ép vékonybélszakasz; B) Zsírmájban a bélboholy felszíni hámja eltűnt; C) Zsírmájban a bolyhok is lelökődtek

Lépték: 100 mikrométer

A nyilak a boholy csúcsát mutatják, ahol a csúcs elhalt 
A)

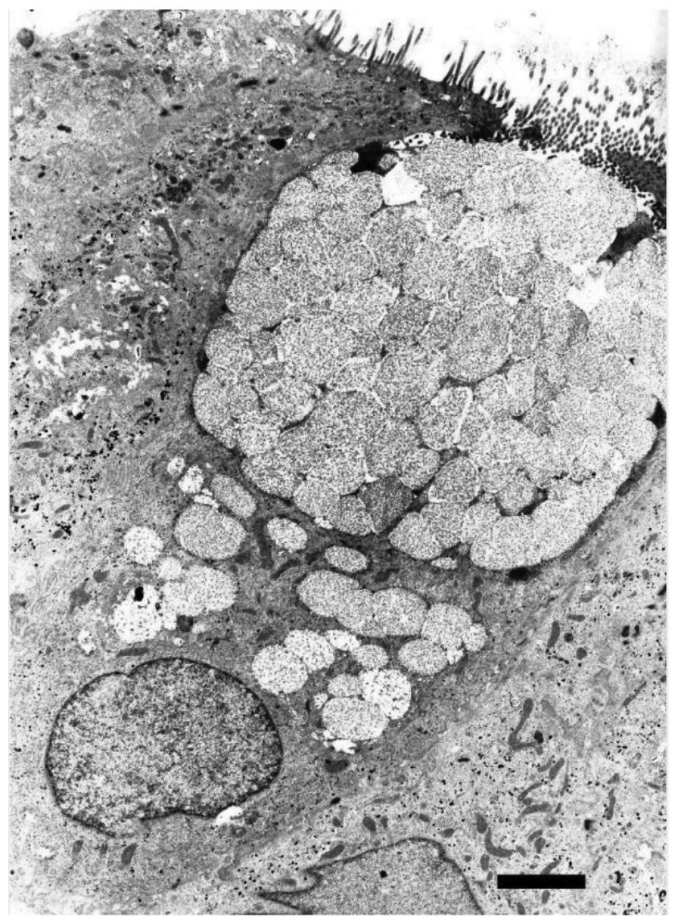

B)

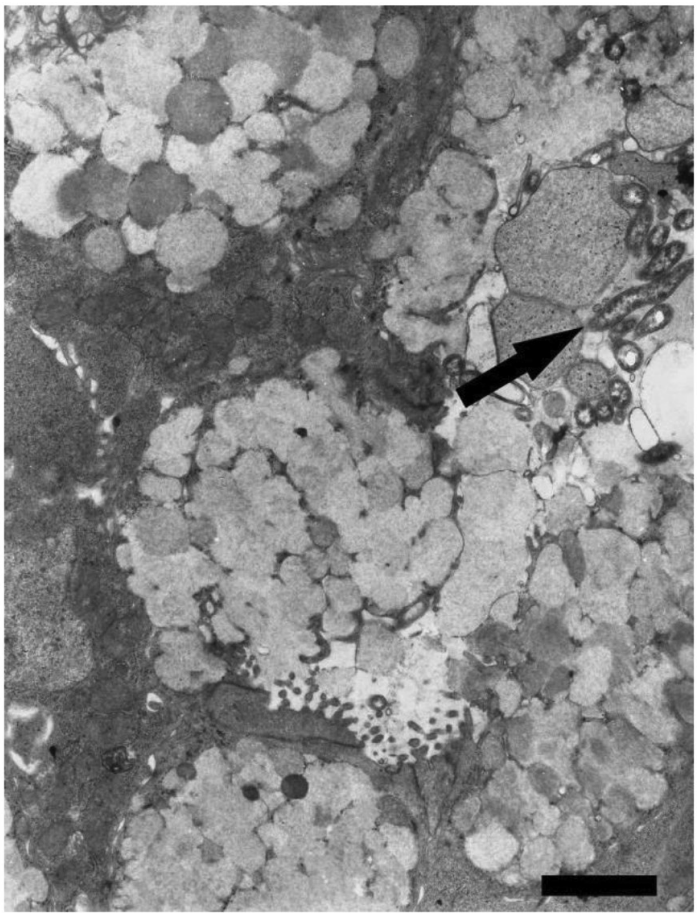

4. ábra

\begin{abstract}
Vastagbél elektronmikroszkópos képe egészséges állatokban és zsírmájban szenvedőkben
A) Egészséges vastagbélrészlet, ép kripta ép kehelysejttel; B) Zsírmájban a vastagbél Lieberkühn-kripta része, ahol a kehelysejtek sérültek és a bélbaktériumok bejutnak a sejtbe

Lépték: 1 mikrométer

A nyíl a baktériumokat mutatja
\end{abstract}

A rutinlaboratóriumi és redoxeltéréseket a 8 . táblázatban bemutatott lipidprofil-változás is tükrözi. Látható, hogy a táphoz adott napraforgóolaj statisztikailag értékelhetô változást okozott a zsírsavösszetétel közel összes elemében. Különösen az olajsav és a linolsav mennyisége nőtt meg a májban, ugyanakkor a dokozahexaénsav mennyisége csökkent, ami a prosztaglandin-bioszintézis útjában és a kapcsolódó immunfunkciókban okozhat jelentős eltérést.

A 9. táblázatban a máj fémion-összetételében látható különbségek jelzik a szöveti károsodást.

A szövettani képek egyértelmúen mutatják a zsírdús táplálás káros hatását (1-4. ábra). A máj, a vékony- és a vastagbél fény- és elektronmikroszkópos vizsgálata igazolta a zsírmáj kialakulását és a bélszakaszok károsodását is.

\section{Megbeszélés}

A nem alkoholeredetû zsírmájbetegség világszerte a leggyakoribb májbetegség. A NAFLD prevalenciája elhízott felnőtteknél 80-90\%, cukorbetegeknél 30-50\%, hyperlipidaemia esetén $90 \%$. A NAFLD prevalenciája a gyermekek körében 3-10\%, az elhízott gyermekek körében $40-70 \%$. Az ultrahangvizsgálatok alapján gyakran alábecsülik a máj károsodásának mértékét, nem mérik fel a béltraktus finom változásait [28].
A zsírmáj állatkísérletes modelljén végzett vizsgálatunkkal azt kívántuk bizonyítani, hogy a 14 napig tartó zsírdús diéta hatására extrém eltérések mutatkoztak több szervben.

A máj zsíros elfajulását a májenzimértékek és metabolitok (ALP, CHOL, HDL-CHOL, UA) szignifikáns változása igazolta. A redox-homeosztázis mutatói nemcsak a plazmában és a májban, hanem a vizsgált bélszakaszokban is jelezték, hogy a zsíros táplálás jelentôs mértékben terhelte a szervezet antioxidáns védekezését. A glutation-redox-rendszer optimális múködése függ a szervezet transzmetilező képességétől. Amennyiben a metilcsoportok koncentrációja szignifikánsan csökken, akkor a szervezet meghatározó metilező ágense, az S-adenozilL-metionin nem képes a DNS, RNS, hiszton és más fehérjék, enzimek térszerkezetének módosítására. A metilcsoportok hiánya miatt az antioxidáns védelmi funkció is sérül, ugyanis a glutation ( $\mathrm{L}$ - $\gamma$-glutamil- $\mathrm{L}$-ciszteinilglicin) szintéziséhez szükséges cisztein nem fog kellő mértékben rendelkezésre állni, mert gátlódik a metionin $\rightarrow$ cisztein átalakulás [21]. A gastrointestinalis traktus különböző szakaszainak antioxidáns védelme a bélszakaszok struktúrájának és funkciójának megfelelően eltérő.

Mind az enzimatikus (szuperoxid-dizmutáz [SOD], kataláz, glutation-redox-rendszer), mind a nem enzimatikus antioxidáns aktivitások (E-vitamin, A-vitamin, ka- 
rotinoidok) a vékony- és a vastagbél mucosa/submucosa és muscularis/serosa rétegeiben szignifikáns különbségeket mutatnak. Az összes antioxidáns aktivitás nagyobb a vékonybél teljes struktúrájában, mint a vastagbélszakaszok azonos rétegeiben [29, 30].

„Short term” kísérletünkben, zsírmájban, azt tapasztaltuk, hogy a vékonybélben az antioxidáns kapacitás továbbra is jelentősen nagyobb volt, mint a vastagbélben. A vizsgált globális mutatók, a redukálóképesség és a $\mathrm{H}$-donor-aktivitás kisebb mértékben változtak, mint az enzimatikus változás mutatója, a szabad-SH-csoport koncentrációja, ami fóleg a glutation-redox-rendszer múködésével korrelál a legnagyobb mértékben. Ennek a paraméternek a koncentrációja mindkét bélszakaszban szignifikánsan lecsökkent. Az indukálható szabadgyökszintek zsírmájban nemcsak az egészséges bélszakaszokhoz viszonyítva, hanem a vékony- és vastagbél viszonyában is szignifikáns különbségeket mutattak. A redoxparaméterekben tapasztalható szignifikáns változások jelentősen károsítják a szöveti struktúrát, amit a szövettani képek megerősítenek.

A hisztopatológiai vizsgálatoknál zsírmájban a májlobulusok centrális részén a hepatocyták megduzzadtak, sejtmagjuk szerkezete fellazult, és különböző méretû zsírcseppek jelentek meg. Az elektronmikroszkópos vizsgálatok a glikogén koncentrációjának csökkenését és a zsírcseppek halmozódását mutatták. A citoplazmában vakuólumok alakultak ki. A szövettani képek jól tükrözik a zsírsav mennyiségében (összes zsírsav mg/g máj: kontroll 19,38 $\pm 1,84$ vs. zsírmáj 95,80 $\pm 8,87$ ) és összetételében történt változásokat.

Zsírmájban a vékony- és vastagbél enterocytái sérültek, szerkezetük fellazult, és gyulladásos folyamatok indultak be. A sérült bélszakaszokon a baktériumok szabadon bejutottak a mélyebb rétegekbe.

A bélbaktériumok száma és összetétele a vastagbél irányában fokozatosan változik és növekszik [31]. A különböző gastrointestinalis betegségekben az egészségesekhez viszonyítva jelentős változáson megy keresztül. A Gram-negatív bélbaktériumok lipopoliszacharid toxinjai egészséges emberek beléból nem szívódnak fel, ám azokban a kórképekben, amelyekben az epesav-koncentráció lecsökken - mint például a gyulladásos bélbetegségekben vagy a súlyos mértékű elhízásban -, az epesavak detergens tulajdonsága, méregtelenítő hatása kevésbé jut érvényre [11, 32]. Ha a bélhám sérül, akkor ezek a baktériumtoxinok könnyebben jutnak be a keringésbe.

A 9. táblázatban a máj fémion-összetételében látható különbségek egyértelmúen jelzik mind a máj, mind a bél funkciójának károsodását.

A bél permeabilitásának változásával a különböző táplálkozási komponensek, a vitaminok és fémelemek (Fe, $\mathrm{Zn}, \mathrm{Ca}, \mathrm{Mg}, \mathrm{K}$ ) felszívódása és hasznosulása is megváltozik. Zsírmájban a fémionok felszívódása a vékonybél enterocytáinak sérülése, illetve helyenkénti lelökődése miatt, valamint a gyulladásos reakciók következtében sérül, továbbá a máj elzsírosodása következtében a májból csak részben ürülnek a toxikus elemek.

Alimentáris zsírmájban az esszenciális $\mathrm{Mg}, \mathrm{Mo}, \mathrm{P}, \mathrm{S}$ és Zn koncentrációja szignifikánsan csökkent, míg a Co koncentrációja nőtt. A Mg- és P-szint csökkenése jelzi az energia-háztartás felborulását és az ATP-vesztést. A Mgkoncentráció jelentős csökkenése és ezzel párhuzamosan a Ca-koncentráció, bár nem szignifikáns emelkedése oxidatív stresszt indukál a foszfolipáz C (PLC) aktiválásával és a foszfoinozitol-difoszfát $\left(\mathrm{PIP}_{2}\right)$ hidrolízisével. A folyamat további lépéseiben aktiválódik a szignáltranszdukciós út, gyulladásos citokinek (IL1, IL6, IL8, TNF $\alpha$, $\mathrm{TNF} \beta$ ), növekedési faktorok (EGF $\alpha, \mathrm{TGF} \beta, \mathrm{NFGF}$, FGF, PDGF) és interferonok szintézise indul be. A Cokoncentráció emelkedése szabad gyökök termelődését fokozhatja a Fenton-típusú reakción keresztül [33].

Kutatócsoportunk a bemutatott eredmények alapján megerősíti, hogy az alimentáris eredetû zsírmáj már korai stádiumban is enyhe fokú gyulladásos folyamatnak tekinthető, mely jelentősen károsítja a gastrointestinalis traktust, és egyben alapját képezheti súlyos metabolikus betegségeknek és gastrointestinalis tumorok kialakulásának.

Anyagi támogatás: A kutatásokat a Semmelweis Egyetem 2/1 PhD-Iskola támogatta.

Szerzôi munkamegosztás: B. A.: A kutatások irányítása, a szabad gyökös vizsgálatok elvégzése, a cikk megírása. S. P.: Az állatokból vett szövettani minták előkészítése. K. I.: A rutinlaboratóriumi paraméterek meghatározása. F. H.: Állatkísérlet kivitelezése, zsírsavanalízis. K. D.: A transzmetilezés vizsgálata. Sz. K.: A fémion-analízis elvégzése. F. E.: A fény- és elektronmikroszkópos vizsgálatok kiértékelése. A cikk végső változatát valamennyi szerző elolvasta és jóváhagyta.

Érdekeltségek: A szerzőknek nincsenek érdekeltségeik.

\section{Köszönetnyilvánítás}

A szerzők köszönetüket fejezik ki Bárkovits Saroltának és Pintér Edinának a kiváló asszisztenciáért.

\section{Irodalom}

[1] Russo MW, Wei JT, Thiny MT, et al. Digestive and liver diseases statistics. Gastroenterology 2004; 126: 1448-1453.

[2] Halmos T, Suba, I. Non-alcoholic fatty liver disease, as a component of the metabolic syndrome, and its causal correlations with other extrahepatic diseases. [A nem alkoholos zsírmáj mint a metabolikus szindróma komponense és kauzális kapcsolatai egyéb kórképekkel.] Orv Hetil. 2017; 158: 2051-2061. [Hungarian]

[3] Hegedús V, Gerô D, Mihály Z, et al. Alimentary induced fatty liver and adjuvant therapy with effective natural bioactive molecules. [Alimentáris eredetû kísérletes zsírmáj és adjuváns kezelése természetes eredetű bioaktív anyagokkal.] Orv Hetil. 2011; 152: 1035-1042. [Hungarian] 
[4] Sabaté JM, Jouët P, Harnois F, et al. High prevalence of small intestinal bacterial overgrowth in patients with morbid obesity: a contributor to severe hepatic steatosis. Obes Surg. 2008; 18: 371-377.

[5] Hu Y, Zhang H, Li J, et al. Gut-derived lymphocyte recruitment to liver and induce liver injury in non-alcoholic fatty liver disease mouse model. J Gastroenterol Hepatol. 2015; 31: 676-684.

[6] Quigley EM, Monsour HP. The gut microbiota and nonalcoholic fatty liver disease. Semin Liver Dis. 2015; 35: 262-269.

[7] Navaneethan U. Hepatobiliary manifestations of ulcerative colitis: an example of gut-liver crosstalk. Gastroenterol Rep (Oxf). 2014; 2: 193-200.

[8] Rojas-Feria M, Castro M, Suárez E, et al. Hepatobiliary manifestations in inflammatory bowel disease: the gut, the drugs and the liver. World J Gastroenterol. 2013; 19: 7327-7340.

[9] Tilg H, Cani PD, Mayer EA. Gut microbiome and liver diseases. Gut 2016; 65: 2035-2044.

[10] Blázovics A, Fehér J, Fehér E, et al. Liver protecting and lipid lowering effects of Sempervivum tectorum in the rat. Phytother Res. 1993; 7: 98-100.

[11] Egresi A, Kovács Á, Szilvás Á, et al. Gut-liver axis in inflammatory bowel disease. A retrospective study. [A bél-máj tengely vizsgálata colitis ulcerosában. Retrospektív tanulmány.] Orv Hetil. 2017; 158: 1014-1021. [Hungarian]

[12] Sipos P, Hagymási K, Lugasi A, et al. Direct effect of bile on colonic mucosa in alimentary induced hyperlipidemy in rats. Acta Aliment. 2001; 30: 25-35.

[13] Sipos P, Hagymási K, Lugasi A, et al. Effects of black radish root (Raphanus sativus $\mathrm{L}$. var niger) on the colon mucosa in rats fed a fat rich diet. Phytother Res. 2002; 16: 677-679.

[14] Blázovics A. Gallstone disease: free radical reactions and the ambivalent role of bilirubin in the pathomechanism of gallstone formation. [Epekőbetegségek: szabadgyökös reakciók és a bilirubin ambivalens viselkedése az epekóképző́dés patomechanizmusában.] Orv Hetil. 2007; 148: 589-596. [Hungarian]

[15] Sipos P, Gamal EM, Blázovics A, et al. Free radical reactions in the gallbladder. Acta Chir Hung. 1997; 36: 329-330.

[16] Blázovics A, Abaza M, Sipos P, et al. Biochemical and morphological changes in liver and gallbladder bile of broiler chicken exposed to heavy metals (cadmium, lead, mercury). Trace Elem Electrolyt. 2002; 19: 42-47.

[17] Sipos P, Hagymási K, Blázovics A, et al. Cholecystitis, gallstones and free radical reactions in human gallbladder. Med Sci Monit. 2001; 7: 84-88

[18] Sipos P, Szentmihályi K, Fehér E, et al. Some effects of lead contamination on liver and gallbladder bile. Acta Biol Szegediensis 2003; 47: 139-142
[19] Lowry AH, Rosenbrough NJ, Farr AL, et al. Protein measure ment with the Folin phenol reagent. J Biol Chem. 1951; 193: 265-275.

[20] Oyaizu M. Studies on product of browning reaction prepared from glucose amine. Jpn J Nutr. 1986; 44: 307-315.

[21] Blázovics A, Sárdi É. Methodological repertoire development to study the effect of dietary supplementation in cancer therapy. Microchem J. 2018; 136: 121-127.

[22] AOAC Official Methods of Analysis. 14th edn. Association of Official Analytical Chemists, Arlington, VA, 1984

[23] Blázovics A, Kovács Á, Lugasi A, et al. Antioxidant defence in erythrocytes and plasma of patients with active and quiescent Crohn's disease and ulcerative colitis: a chemiluminescent study. Clin Chem. 1999; 45: 895-896.

[24] Sedlak J, Lindsay RH. Estimation of total protein-bound and nonprotein sulfhydryl groups in tissue with Ellmann's reagent. Anal Biochem. 1968; 25: 192-205.

[25] Folch J, Lees M, Sloane-Stanley GH. A simple method for the isolation and purification of total lipids from animal tissues. J Biol Chem. 1957; 226: 497-509.

[26] AOAC Official Methods of Analysis. 15th edn. Arlington, VA, 1990.

[27] Szentmihályi K, May Z, Szénási G, et al. Cisplatin administration influences on toxic and non-essential element metabolism in rats. J Trace Elem Med Biol. 2014; 28: 317-321.

[28] Bellentani S, Scaglioni F, Marino M, et al. Epidemiology of nonalcoholic fatty liver disease. Dig Dis. 2010; 28: 155-161.

[29] Loguercio C, Di Pierro M. The role of glutathione in the gastrointestinal tract: a review. Ital J Gastroenterol Hepatol. 1999; 31: 401-407.

[30] Blau S, Rubinstein A, Bass P, et al. Differences in the reducing power along the rat GI tract: lower antioxidant capacity of the colon. Mol Cell Biochem. 1999; 194: 185-191.

[31] Sekirov I, Russel SL, Antunes LC, et al. Gut microbiota in health and disease. Physiol Rev. 2010; 90: 859-904.

[32] Bertók L. (ed.) Natural resistance: the role of bile acids and endotoxins. [Természetes ellenállóképesség: epesavak és endotoxinok szerepe.] Scientia Kiadó, Budapest, 2002. [Hungarian]

[33] Szentmihályi K. Metal element homeostasis and oxidative stress in pathological processes. [Fémelem-homeosztázis és oxidatív stressz patológiás folyamatokban.] Orv Hetil. 2019; 160: 14071416. [Hungarian]

(Blázovics Anna dr., Budapest, Üllői út 26., 1085 e-mail: blazovics.anna@pharma.semmelweis-univ.hu)

A cikk a Creative Commons Attribution 4.0 International License (https://creativecommons.org/licenses/by/4.0/) feltételei szerint publikált Open Access közlemény, melynek szellemében a cikk bármilyen médiumban szabadon felhasználható, megosztható és újraközölhető, feltéve, hogy az eredeti szerzỏ és a közlés helye, illetve a CC License linkje és az esetlegesen végrehajtott módosítások feltüntetésre kerülnek. (SID_1) 